\title{
The Development of Jathilan Performance as an Adaptive Strategy Used by Javanese Farmers
}

\author{
$\bowtie$ Agus Maladi Irianto \\ Fakultas Ilmu Budaya, Diponegoro University, Indonesia \\ Jalan Prof. Soedarto Tembalang Semarang, Indonesia \\ $\triangle$ E-mail: ami.fibundip@gmail.com
}

Received: February 29, 2016. Revised: March 23, 2016. Accepted: June 2, 2016

\begin{abstract}
This paper is aimed at describing adaptive strategy used by supported community to preserve and develop Jathilan, Javanese traditional ritual art performance. In describing the aim, the most fundamental nature and meaning attached in the artistic performance had been studied. Qualitative method was employed through literature review and field study. This study located in Magelang Regency, Central Java. The Jathilan in this paper is seen as cultural identity for its supported community, that has a specific role socially and ritually. The supported community, in addition, believes that this traditional art is not only acted as an entertainment, but also a facilitator for their hopes and prays. Despite some changes have influenced the differences of style and variation in the performing art, however, the changes themselves are the manifestation of adaptive strategy had from the supported community to preserve and conserve Jathilan performing art.
\end{abstract}

Keywords: Jathilan; adaptive strategy; farmer community; integrative need

How to Cite: Irianto, A. M. (2016). The Development of Jathilan Performance as an Adaptive Strategy Used by Javanese Farmers. Harmonia: Journal of Arts Research And Education, 16(1), 38-48. doi:http://dx.doi.org/10.15294/harmonia. v16i1.5213

\section{INTRODUCTION}

To establish and improve one's living standard, a man needs to fulfil several needs which have been accepted universally. There are stages in this human needs, (1) primary or biologic need, it is resulted from biologic and organism aspects, (2) social needs, it reflects human as social beings and is naturally structural, it is manifested as results of human effort in fulfilling their primary needs that have to involve others in a certain social life; often referred as instrumental need, and (3) integrative or simbolic needs, it reflects human as cultural human being; it is seen from the basic nature of human as a thinker, morals, and have feelings, used to integrate several needs into a system that is accepted morally, understood by logic, and accepted by feelings (Suparlan, 1985, pp. 5-6, and Tuner, 1986, pp. 5-6).

Art is an integral human need which is used to improve and establish standard of living. It is believed that no matter how simple one's life is, they will keep seeking and using aesthetic aspect of life through art in the middle of their struggle to keep their primary needs. However, it needs to be realized that environment and the needs of every society are not always the same. As a result, every society will develop an adaptive strategy to satisfy each integrative need. Departed from the different development strategy, thus, there will be different manifestations of art for each society. A farmer community in Javanese village, for example, has developed art as an integrative need and, functionally, relates it to the culture in the area where they 
were living since long time ago. Art, as for Javanese village farmers, is seen as a medium to legitimate their status and preserve their society identity (Danandjaja, 1985, p. 19; Koentjaraningrat, 1994, pp. 211-220). One of performing art has by a Javanese village farmer community that is still preserved till recently is Jathilan. Jathilan itself is one of traditional performing art that act as cultural identity for the Javanese farmer community (Irianto, 20142015). Jathilan which uses kuda kepang in its performance, is considered as one of the connector of ritual values with the concepts of simplicity and mutual cooperation between people in one farmer community (Nugraheni, 2014; Nurani, 2008).

As a ritual medium, the Javanese farmer community carries out Jathilan as a medium to pray for safety, prosperity, and welfare to God. However, in line with the development of technology, like TV or video player, recently, there are a considerable number of VCD and DVD contained in the video of Jathilan in a more solid, concise, and interesting package (Sutiyono, 1994). The development of Jathilan performance has then resulted in the development that produces different style, variety, and even function for its supported community.

The problem raised in this phenomenon is why does the development of Jathilan experience the shift of function, even though, the background of its supported community remains at a group of community living in a village who keeps controlling a plot of land effectively and living in the Javanese culture environment? How does the adaptive strategy developed by the supportive community preserve the existence of Jathilan performing art?

Departed from these questions, thus, in order to study the function shift and adaptive strategy had by a supportive community to preserve Jathilan cannot be separated from the dynamic development of the culture surrounding it. By studying culture had by the Javanese village farming community, the contextual picture of Jathilan will be seen, both relating to the nature of Jathilan and to the adaptive strategy used by the community to develop the traditional performance itself. The Jathilan is addressed by the Javanese village farmer community as a medium to legitimate their existence and preserve identity. It is also part of their cultural expression (Koentjaraningrat, 1994, pp. 211-212). As explained by Rohidi (2000, p. 41), culture can be understood as (1) living guidance used as a comprehensive blueprint or design for its supported community; (2) system of symbol, meaning appropriation and cognitive model that is transmitted through symbolic codes; and (3) adaptive strategy to preserve and develop one's life in confronting the environment and resources around their living environment.

The statement is in line with Geertz (1973, p. 89) and Suparlan (1985, pp. 1-19) that culture is an entire human knowledge contained with a set of knowledge model that is selectively used to understand and interpret the knowledge they face, as well as to encourage and create the needed action. From the statement, one can learn that culture is a set of guideline used by human to adapt to the environment or to fulfil their living needs. Moreover, it also needs to be realized that art exists, developed, and standardized through social tradition held by its supported community, so that the development of art is indirectly in line with the shift of culture that is obeyed by the community (Irianto, 2005, pp. 1-7).

In accordance with the aim of previous studies, this paper is attempting to study the adaptive strategy of the supported community in order to preserve and develop Jathilan. To describe this, the nature and meaning behind the performance of Jathilan to its supported community will be discussed. The interpretation will be reflected in a way of life, beliefs, and values are impregnated by community living in a certain living hood.

To describe the contextual picture of Jathilan in Javanese village farmer environment, one cannot identify this only from the artistic perspective. It is because inside the performance, there are aesthetic 
and ideology aspects of its supported community that meets (see Keeler, 1987, p. 17). Thus, the existence of Jathilan is ideal not to be seen from the aesthetic perspective, but also from the point of view that the existence of the performance is also influenced by its dynamic functions and meanings for its supported community (Djelantik, 2008). Functions and interpretations implicitly reflected in the traditional performing art will be dynamically related to the values that need to be faced by its supported community.

\section{METHOD}

There were two stages of research done by researcher in this study, the literature review and field study. In the stage of literature review, the researcher received a considerable number of references related to the historical data of Jathilan existence in Indonesia. The references were collected by researchers from journals, newspapers, internet, proceedings, textbooks, and reports from the previous study conducted by researcher. After conducting the literature review stage, the next step was deciding the location for field study which was in Magelang regency, Central Java, Indonesia. The decision of location was based on two basic considerations. First, among regencies in Central Java, the center of Jathilan performing art where the performance is still continually preserved is in Magelang regency. It was proven by the existence of 153 performing art groups which still actively rehearse and perform Jathilan. Second, the location of Magelang regency which is exactly beside Jogjakarta province that is well-known as the center of the art of Javanese society.

In the stage of field study, researcher collected the data by doing observation and deep interview with several such persons. The results of the observation and interview were used as a guideline to comprehensively describe the existence of Jathilan. Observation, specifically, was purposefully used to record all conditions and experiences that were previously observed by researchers. Whereas the interview was addressed to source persons or key informants who were considered reliable in giving information related to the existence of Jathilan.

Furthermore, in relation to the data analysis, this study was conducted by employing descriptive-analytic approach, that is, an approach aiming at describing a relationship between phenomena in a certain community (Creswell, 1994). Through this approach, the study attempts to find out an understanding about the reasons, background, as well as interpretations which underlie action and decision-making taken by supported the community in addressing the existence of Jathilan. Data collected from the research was implemented as a model, perspective, motivation, knowledge, and background of the community in developing the traditional performing art.

\section{RESULT AND DISCUSSION}

Based on research, the researcher has received a comprehensive description about Jathilan. Broadly, the description explains about: (1) the background of the community that supports Jathilan, (2) cultural meanings and messages contained in Jathilan, and (3) Jathilan as the medium for slametan, communal feast from Java. The following is a description of the results.

\section{The Background of Community Support- ing Jathilan}

As explained previously, this research took place in Magelang Regency, Central Java. Magelang regency is located between mountains, consists of 21 districts, and owns hundreds of traditional performing arts. The name of art types spread in those 21 districts are Topeng Ireng, Soreng, Wayang Orang, Kubrosiswo, Jathilan, Dayakan, Topengan, Ketoprak, Prajuritan, Jelantur, Warokan, Dolalak, Srandul, Lengger, Gangsir Ngentir, Reog, Sholawatan, Ande-ande Lumut, Gatholoco, Rodhat, Manasuka, Langentoyo, Kuntulan, Cekok Mondol, Balilele, and Cakarlele. Based on the record 
had by Department of Tourism and Culture in Magelang Regency on July 2015, there are 723 types of traditional performing arts spread in 21 districts (Please see Table 1).

Table 1. Number of Traditional Performing Arts in Magelang Regency

\begin{tabular}{cc}
\hline $\begin{array}{c}\text { Types of Perform- } \\
\text { ing Arts }\end{array}$ & $\begin{array}{c}\text { Number of } \\
\text { Performing Art } \\
\text { Groups }\end{array}$ \\
\hline Topeng Ireng & 100 \\
Soreng & 40 \\
Wayang Orang & 5 \\
Kubrosiswo & 98 \\
Jathilan & 153 \\
Dayakan & 40 \\
Topengan & 3 \\
Ketoprak & 56 \\
Prajuritan & 9 \\
Jelantur & 6 \\
Warokan & 20 \\
Dolalak & 5 \\
Srandul & 4 \\
Lengger & 8 \\
Gangsir Ngentir & 3 \\
Reog & 21 \\
Sholawatan & 131 \\
Ande-ande Lumut & 1 \\
Gatholoco & 2 \\
Rodhat & 2 \\
Manasuka & 1 \\
Langentoyo & 1 \\
Kuntulan & 2 \\
Cekok Mondol & 1 \\
Balilele & 3 \\
Cakarlele & 8 \\
\hline Total & in 2015 \\
ture Magelang Regency & \\
\hline Source: Department of Tourism and Cul- \\
Tara
\end{tabular}

Meanwhile, written in the data, numbers of Jathilan performing art group are the most if it is compared with other traditional performing arts. Based on records from Department of Tourism and Culture Magelang Regency until July 2015, there are 153 Jathilan performing art groups. The question raised towards this phenomenon, why does Jathilan performing art have more enthusiasts than other performing arts? Based on several source persons, learning Jathilan does not need a special education. It only needs a simple introduction about the art and direct practice in society. Thus, whoever the person is, they can perform the performance. This performing art exists and is developed as a result of collective intelligence that is inherited from one generation to another generation orally, from one mouth to another mouth through direct practice. From this simple introduction, thus, Jathilan performing art becomes popular among society, particularly in Magelang Regency (Irianto, et al., 2014-2015).

The popularity of Jathilan also spreads to all districts in the area of Magelang Regency, although the comparison of numbers of Jathilan performing art groups are not the same for each district. By the spreading of the arts in every district, the popularity of Jathilan is somehow clearly seen. The comparison of a number of the groups, however, cannot be compared with the numbers of people living in each district. For example, people live in the Bandongan district in 2014 was 56,634 people based on data from the Central Bureau of Statistics of Magelang Regency and at the same time only one performing art group existed in this district. On the other hand, in the same year, in Sawangan district, there were only 56,010 people living in the district, but it had 34 Jathilan performing art groups. Further, the distribution of Jathilan performing art group in Magelang Regency can be seen in the following Table 02 . 
Table 2. Numbers of Jathilan Performing Art Group and Its Distribution in Magelang Regency

\begin{tabular}{|c|c|}
\hline Districts & $\begin{array}{c}\text { Number of } \\
\text { Groups }\end{array}$ \\
\hline Bandongan & 1 \\
\hline Borobudur & 20 \\
\hline Candimulyo & 12 \\
\hline Dukun & 10 \\
\hline Grabag & 3 \\
\hline Kajoran & 5 \\
\hline Kaliangkrik & 9 \\
\hline Mertoyudan & 8 \\
\hline Mungkid & 5 \\
\hline Muntilan & 9 \\
\hline Ngablak & 1 \\
\hline Ngluwar & 4 \\
\hline Pakis & 2 \\
\hline Salam & 4 \\
\hline Salaman & 6 \\
\hline Sawangan & 34 \\
\hline Secang & 2 \\
\hline Srumbung & 6 \\
\hline Tegalrejo & 6 \\
\hline Tempuran & 1 \\
\hline Windusari & 5 \\
\hline Total & 153 \\
\hline
\end{tabular}

Source: Department of Tourism and Culture Magelang Regency in 2015

Based on both observation and interview results with several source persons, the enthusiast of Jathilan performing art in Magelang Regency is a group of society comprises of people living in villages and working as farmers. They have been bounded with tradition and feelings since very long time. By keeping obeying tradition and feelings, thus, they think that the world of farming and themselves are part of an interrelated aspect. People in these districts are working as a farmer for not only collecting profits, but also to meet the need of their modest family or, in other words, to receive their rights to live in paras subsistence (Irianto, et al. 2014-2015).
As a form of folk dance originated from farmers, Jathilan is considerably different from dance originated from the palace. If classical dance from the palace is resulted from a dance choreography that is distilled strictly, on the other hand, Jathilan performance as a folk performing art is more of a flexible dance type. Even, according to Sedyawati (1984), dance originated from outside palace is usually expressed hardly, meanwhile, the dance originated from inside the palace is smoother and slower. Jathilan belongs to an art originated from outside palace which is expressed spontaneously and hardly. In addition, several source persons also mentioned that the word "jathilan" itself comes from a Javanese word called "jathil" which means jumping or hoping joyfully. However, based on another source person, "jathilan" comes from the Javanese term "Jan ThilThailand" which means whole heatedly moves all parts of body dynamically till sometimes look rough. Therefore, a Jathilan dancer has to wholeheartedly move all of his body dynamically to express happiness, even though it will look rough.

It has to be admitted that knowledge of farmer society basically tends to be social rather than economical. Irianto and Thohir (2004) claim that value and attitude had by farmer society tends to prioritize tranquility and peace without a need to push their desire more than what they have currently. This is what is usually known as value and attitude which maintains small society tradition and local value. For example, farmers have still stuck to the principle of receiving income equally, although they have to live on stage of paras subsistence. However, in line with the development of civilization, the farmer society also has to get involved in economic activity and depends on broader market (larger tradition).

Among the contradict condition, Jathilan performance grows and develops in Magelang Regency. Jathilan here is actually able to accommodate the condition that is faced by the farmer society. As stated by one of such person, the numbers of Jathilan 
performing group in Borobudur District, for example, is considerably numerous since the area is located around the world tourism object that is Borobudur temple which frequently performs the attraction of Jathilan. By developing the existing creativity, Jathilan from Borobudur District has been able to be one of entertaining art as well as tourism commodity in Magelang Regency. Different from what happened to Srumbung District, located on the slope of Merapi mountain, the society is still maintaining the originality of Jathilan as a medium to communicate with their ancestors. Even though the number of Jathilan performing art group in Srumbung district is not as many as in Borobudur District, however, the existence of traditional art in Srumbung District is used by the society to ask for protection from their ancestors from the dangers of volcanic eruption (Irianto, et al. 2014-2015). From the explanation, it can be understood that the existence of Jathilan in Magelang Regency is able to preserve small tradition had from the supported community in one hand, and rationally can be also used to adhere bigger tradition developed in its surrounding in the other hand as happened in Srumbung and Borobudur District.

\section{Cultural Meanings and Messages in Jathilan Performing Arts}

From the description of background of the supported community of Jathilan in Magelang Regency, thus, the traditional performing art itself must contain meanings and messages in the form of ideas, abstraction, attitude, as well as belief and experiences had by the farmer community. Moreover, the performing art itself exists and is developed after it is standardized through a social tradition of its supported community. Therefore, the development of performing art is indirectly in line with the changing or shift of culture had by the society.

Then, what kind of artistic performance Jathilan is? The performance of Jathilan is started by music accompaniment that is played by the music player. After several minutes, dancers acting as warriors are coming to the stage while riding on an artificial horse made from woven bamboo or usually called as jaran kepang in Javanese term. The music accompaniment has to be continuously played until the end of the performance. The next scene is when the dancer acting as a giant or butho or a big animal look like a lion, which is known as barongan comes to the stage to chase the soldiers. Here, at this time, usually the dancers are possessed. While dancing, the possessed dancers will show some attractions, like, breaking coconut with bare head or swallowing glasses. The scene is ended by a dancer acting as the figure of a prince who will solve all problems (Irianto, et al. 2014 \& 2015).

Types of Jathilan dance, as informed by source persons, are: Pariaksi, Lampah Mletik, Pincangan, Pencikan, Teposan, Riyepan, Lampah Satrio, Pancak Jonggo, Untu Walang, Lampah Mbalik, Sembiran, and Larikan. In order to dance those types of dances, practice is needed. Several movements practiced by the dancers are the movement of hand waving back and forth, movement of thumb flicking twice, movement of cutting grass, movement of horse shifting to the right, left, and forward, movement of horse drinking, etc. In one group of Jathilan performer, it usually consists of eight music players. Whereas, the Jathilan dancers usually consist of 10-16 people.

The next question will be who was the first creator of Jathilan performance? Based on several literature reviews and interviews with key informants, there is no one knows about the first creator of Jathilan. The same as other traditional arts, the creator of Jathilan performing art is anonymous. According to Soedarsono (1990), the weakness of traditional art performing is its manifestation that will be disappearing right after the performance is over. It is different to fine arts, that still can be enjoyed even after the exhibition is over, fine art can also be kept for unlimited time. The same also works for the data related to the time when a certain performance was performed and developed in Javanese 
cultural environment. There is no one has ever exactly recorded the data. However, more or less the Javanese culture was first existed and developed was when The Pegeud started to publish his book entitled Javanese Volksvertoningen in 1930s. That year is considered as the year when Javanese traditional performing art started to exist in the Javanese culture environment (Kuswarsantyo, 2013).

The performance of traditional art, which uses equipment in the form of artificial horse, is usually held in village festivity occasion that is known as merti desa. Merti Desa is an annual festivity for a public that is usually held by farmers in most of Javanese villages. This occasion is usually held after harvest or before planting season. The purpose is to clear the village from the evil spirit, disease, as well as disaster. Therefore, holding the performance of Jathilan means also a form of social solidarity from its supported community as to fulfil their hope of being free from disaster (Irianto, et al. 2004-2015).

The performance of Jathilan traditional performing art is usually adapted the story of Panji Asmarabangun, a set of stories from the period of classical Javanese in the era of Kediri kingdom. It tells about heroic and love story between two central characters, Raden Inu Kertapati (Panji Asmarabangun) and Dewi Sekartaji (Galuh Candrakirana). Besides in Jathilan, the story has also been widely adapted in other traditional performances.

Related to this information, the key informants (based on data from Irianto, et al., 2014-2015), added that Jathilan performance actually has several versions. From the versions, there are three dominating versions: (1) version that represents the cavalry of Pangeran Diponegoro (Prince Diponegoro) in beating Deutch colonialism, (2) version that depicts heroic story of Raden Patah which is help by Wali Songo in introducing and spreading Islam in Java, as well as, (3) the Mataram version that tells about the practice of war lead by Pangeran Mangkubumi who had title as Sri Sultan Hamengku Buwana I, the King of Jogjakarta Kingdom, to fight against Deutch.

Despite many versions of Jathilan performance, the similarity lies in the usage of the wooden bamboo artificial horse or Jaran Kepang as particularity property used during the performance. Minimally, four flat, artificial wooden bamboo horse is used in Jathilan performance. The horse itself has different colors, there are white, red, yellow and black. Based on interview with several informants, colors attached in the artificial horses are believed to be able to contain meanings about human's natural character. White illustrates the nature of meaningful kindness of human being (mutmainah). Red illustrates the anger (amarah) side of a human which means brave, yellow illustrates the nature of human being that is supiyah which means tempted desire to possess, and black illustrates aluamah which means greedy. Research by Prakosa (2006) states that Jathilan is specifically a depiction of troop movement by imitating and mimicking horsemen. Simultaneous and rhythmic stomping legs are clearly seen, meanwhile the hands are stickily holding the artificial horse. In addition to this, Kuswarsantyo (2013) argues that Jathilan is thematically a heroic dance illustrating troop who are practicing war.

Another question raised of why the horse is used as an important symbol in Jathilan performance. Informants or source persons mention that horse is a symbol of strength and courage, as well as a favorite animal of Javanese kingdom knights (Irianto, et al., 2014-2015). The argumentation is supported by Pigeaud that is cited by Kuswarsantyo (2013) that belief in ancient Javanese society regards horse as a very important animal that the existence of horse is closely related to supernatural power in that ancient era of Java. It is believed that inside the body of a horse, especially at the head part, lies the spirit of the ancestors. Thus, the horse becomes symbol of strength as well as the characteristic of Jathilan. Moreover, the horse is the symbol of strength. Naturally, the horse has much spirit and has functioned as a "street com- 
pass". The supported community of this traditional performing art believes that by using property of artificial horse, there will be ancestor spirits that come to face disasters.

Beliefs and meanings had by supporting community towards Jathilan as described previously, basically explains that the traditional art is a medium which is able to accommodate ideas from its supported community. If Jathilan performance is medium to accommodate the ideas of supported community, thus, it has been integrated structurally and mentally in the cultural system supported by the concerned society (Geertz, 1973). If this has been integrated in cultural system, it has been used as guidance by its supported community to realize an action. Within this system, embedded sets of cognition, symbol, and meaning that are integrated comprehensively.

In line with the thought, thus, the symbol system is used selectively by its supported community to communicate, preserve, relate, behave, and act to fulfil its integrative needs. The supported society believes that by holding Jathilan, which contains social function, togetherness in the attempt to strengthen the identity and integrity of supported community is able to be created. Besides, based on observation, it can be said that Jathilan performance is able to create the atmosphere of solidarity between farmer dancers and farmer audiences in Javanese cultural environment. Moreover, tradition and local moral value about social and ritual meaning are attached in Jathilan. Social meaning contained in this traditional performing art is reflected in the society's life, such as, mutual assistance, helping each other, as well as seeing problems as collective issues. On the other sides, supported community also needs safety and protection from "The Caretaker" of nature or ancestor spirits which are then expressed through ritual (Irianto, et al., 2014-2015).

\section{Jathilan as a Medium of Slametan}

As a farmer community, dependency of human towards nature greatly influences the dynamics of life of community supports Jathilan performing art. Human's dependency on planting and harvesting season need an expression medium which able to create the happiness nuance as well as togetherness between people in society. However, when they, people in the community, have to endure dry season or disaster, they do not have ability to overcome it. As a result, they need help from their ancestor spirits which are believed to be able to control the nature condition.

Condition of nature is understood as areas full of spirit's existence. In order to be able to understand the supernatural of the universe, a medium is needed to facilitate the communication between human and nature (Irianto and Thohir, 2004). Communication between human and nature is expressed through certain rituals, and one of it is expressed through performance of Jathilan in which within the performance are the prayers and wishes of the supported community.

A community that supports Jathilan performance believes that traditional performing art has the ability to facilitate their prayers and wishes. The prayers and wishes, in Javanese farmer community perspective, are expressed through the ritual process often called as slametan. Prayers in Javanese Jathilan, kuda kepang, or reog performance, generally aims at asking for safety to the Creator during the performance (Ambarwangi, et al., 2014, pp.3745). Slametan is believed as a medium that is able to create harmony horizontally and vertically. Through slametan, society believes their social position as a human being is not different to the others; they also believe that by holding slametan, they will be free from supranatural spirits haunted them. Slametan is able to accommodate social and ritual demand (Geertz, 1983, p.13). The belief, based on Soedarsono (1990, p.4) was basically existed in the era of pre-Hinduism, known as magi simpatetis belief. It is part of an ancient belief that influences the belief of society in the scope of Javanese culture. It means that every event 
happened around the human living environment is influenced closer to the event that has the power of magi simpatetis.

Society supporting Jathilan performing art in Magelang regency also strengthens the argument. Based on observations in the field and interview with several key informants, Jathilan is considered as one medium that has the power of magi simpatetis. For example, Jathilan performance's supported community in Srumbung district, Magelang regency, who lives on the slope of the Merapi mountain believes that the area they are living in belong to disaster-prone areas since the volcano may erupt in no time. They realize that they can do nothing to prevent or stop the disaster to happen, however, they keep hoping that the disaster will not destroy their family and neighbor around the environment. One form of expressing the wishes is through holding ritual that is Jathilan (Irianto, et al., 2014-2015).

As part of ritual procession, therefore, meaning and the power of magi simpatetis contained in Jathilan is more emphasized. To hold the ritual procession, according to one informant, a community needs to follow certain ritual rules that have become a tradition and cannot be left by both dancers and the organizer. In order to give illustration regarding to the ritual rules, researcher has created a documentary film of a Jathilan performance in Krajan, Ngargasoko Village, Srumbung District, Magelang Regency. In this place, there is one Jathilan performing art group, namely Panca Budaya that for some informants are belong to a Jathilan performing art group that preserves the originality of the art which is inherited by their ancestors (Irianto, et al., 2014-2015).

Around two kilometers from the village, there is a field which is believed to local communities as a gate to the "kingdom" of supernatural spirits that "control" the area of Mount Merapi. In the area also there is a confluence of two small rivers called Tempuran which is believed to be a sacred place for purifying one self. For this reason, before Jathilan is performed in front of the gate of the "kingdom" of Merapi, all stage properties, like, the artificial horse, musical instrument, etc., which is used during the performance need to be purified in Tempuran river. The process of purifying or bathing is usually known as ngguyang jaran. To complete the process of ngguyang jaran, society prepares offerings to be brought to the purifying or bathing spot. The offering contains seven types of flowers, snacks, cooked chicken, boiled chicken eggs, coins, and burned incense.

The ritual process of Jathilan in Krajan, Ngargosoko Village, Srumbung District, Magelang Regency is described in Irianto et al. (2014-2015):

Before the performance of Jathilan is started, a ritual is done by a spiritual figure in the village. The ritual is done by parading the stage equipment to the river which is believed sacred to be bathed. The stage equipment is eight to ten artificial horses, giant masks, a born-again, a set of musical instrument, as well as an offering. In the sacred river, the horses are bathed or purified. Meanwhile, the offering contains of seven-type of flowers, snacks, cooked chicken, boiled eggs, coins, and burned incense are devoted to the spiritual spirit of the village. The offering ritual is believed as permission to the ancestors for the sake of the performance to run well.

If the ritual procession ngguyang jaran is completed, thus, all entire crews and dancers will come to the field without voices or played instruments. The distance between the bathing spot to the stage of performance is more or less one kilometer which must be reached by climbing a mountain cliff. After everything is set up, the performance starts.

One form of communication between supported community with supernatural spirits in the area is usually reflected from the scene of trance, possessed or what society called as ndadi which are unconsciously expressed through the dancers of Jathilan. When the dancers are possessed, it is believed that the spirits possess the dancers are the supernatural spirit haunting the place where Jathilan is 
performed. The scene performing the possessed dancer is in fact becoming the most awaited scene by the audiences. The possessed dancers are acting strange. Among the strange actions are screaming without any clear meaning, both hands are strongly held in fist, both legs are strained, both eyes are closed or even if it is opened, only the corneas are shown. Possessed, or ndadi in Javanese, does not only happen during the Jathilan performance. In other similar performances in Central Java, ndadi can be also experienced by audiences since they might be affected by the possessed dancers. In fact, the moment of ndadi itself that makes performances, like Jathilan, Reog, or Keda Kepang are interesting (Wiyoso, 2011; Ambarwangi, 2014).

If Jathilan dancer is possessed, after that, the role of a "tamer" to guide possessed dancers to dance by following the rhythm of Gamelan, Javanese traditional music. The "tamer" will also whisper a certain mantra while pulling the hair of the possessed dancers. While mantra has been whispered, both ears of the dancers are slowly blown. The purpose is to give suggestion to the subconscious mind of the possessed dancers. On the other hand, through the medium of the possessed dancers, the "tamer" also leaves messages to the spirits to keep and protect society from disaster and threats. After finishing whispering, the "tamer" lifts the body of the dancers and drops it to the ground, afterwards. At the moment when the body drops to the ground, the dancer is back to their sense. Finally, they are dancing according to the rhythm of the music accompaniment (Irianto, et al., 2014-2015).

\section{CONCLUSION}

Based on data taken from the field of study and literature review, the conclusions are:

Performance of Jathilan is ideal not only studied from the aesthetic point of view, but also from the cultural identity perspective of its supported community. This is caused by the nature of Jathilan which is closely related or affected by the concept of culture embraced by the community. The concept of culture will give us direction about adaptive strategies to preserve Jathilan which basically cannot be separated from the dynamic of culture accompanying it.

Jathilan performance considers to be one of the most popular traditional performing art in the community of farmers rather than other traditional performing arts. The popularity is gained since the art is able to accommodate the condition faced by the supported community. The community believes that the art can be used as medium to preserve small tradition held by society as well as to be used as medium to follow the bigger tradition in its surrounding, rationally.

One of the specific characteristic of Jathilan is the use of artificial horse known as Jaran Kepang. The supported community believes that horse symbolizes strength and bravery, even specifically, head of the horse is believed to be the place that has the spirit of ancestor in it. Therefore, by using the artificial horse as property, it is believed that people will have the strength to face disaster that they might face. Belief and meaning about the horse basically explain that the performing art of Jathilan is a medium to be used to accommodate appreciation and the ideas of the supported community.

Jathilan performance is believed by society for not only to create happiness and togetherness, but also as a medium to facilitate prayers and wishes. Jathilan performing art is also identified as asocial activity namely slametan that is regularly done by Javanese farmers. Through slametan, society believes that their social position is similar to other person positions. Society also believes that by holding slametan, they will be free from disturbance caused by supernatural power. The Javanese farmer community believes that slametan is able to accommodate social and ritual demand.

As ritual medium, the Javanese farmer community holds Jathilan performance as a medium to worship for safety, prospe- 
rity, and welfare. However, along with the development of technology, society packs Jathilan performance to be more solid, concise, and entertaining. Although the recent performance experiences some changes in style and variation, however, the existence of the performance itself belongs to a form of adaptive strategy by its supported community to maintain and preserve the performance of Jathilan, functionally.

\section{REFERENCES}

Ambarwangi, S., \& Suharto. (2014). Reog as Means of Students' Appreciation and Creation in Arts and Culture Based on the Local Wisdom. Harmonia Journal of Arts Research and Education, 14(1), 37-45.

Brandon, J. R. (1970). Theatre in Southeast Asia. Cambridge, Massachusetts: Harvard University Press.

Creswell, J. W. (1994). Research Design. Qualitative \& Quantitative Approaches. USA: SAGE Publication.

Danandjaja, J. (1985). Pantomim Suci Betara Berutuk Dari Trunyan, Bali. Jakarta: Balai Pustaka.

Djelantik, A. A. M. (2008). Estetika Seni. Jakarta: Masyarakat Seni Indonesia

Geertz, C. (1973). The Intepretation of Culture. N.Y: Basic Books.

Geertz, C. (1983). Local Knowledge. New York: Basic Books.

Irianto, A. M. (2005). Erotika Petani Jawa Memuja Dewi:Tayub, Antara Ritualitas dan Sensualitas. Semarang: Lengkongcilik Press

Irianto \& Thohir. (2004). Ekosistem Dieng dan Kebijakan Daerah Kabupaten Wonosobo. Research report. Semarang: Puslit Sosbud LPPM Undip

Irianto. (2014-2015). Mengemas Kesenian
Tradisional Dalam Bentuk Industri Kreatif, Studi Kasus Kesenian Jathilan. Research report. Semarang: LPPM Undip.

Koentjaraningrat. (1994). Kebudayaan Jawa. Jakarta: Balai Pustaka.

Kuswarsantyo. (2013). Seni Jathilan: Bentuk, Fungsi, dan Perkembangannya (19862013). Disertaion. Yogyakarta: Universitas Negeri Yogyakarta.

Nugraheni, M. C. (2014). Analisis Sosiologi Budaya Dalam Kesenian Tradisional Jathilan Tri Tunggal Muda Budaya Dusun Gejiwan Desa Krinjing Kecamatan Kajoran Kabupaten Magelang. ADITYA-Pendidikan Bahasa dan Sastra Jawa. 4(5), 71-75

Nuryani, W. (2008). Nilai Edukatif dan Kultural Kesenian Jathilan di Desa Tutup Ngisor, Magelang Jawa Tengah. Thesis. Yogyakarta: Pascasarjana, Universitas Negeri Yogyakarta.

Prakoso, R. D. (2002). Kesenian Jaranan Kota Surabaya. Thesis. Surakarta: STSI Surakarta.

Rohidi, T. R. (2000). Kesenian dalam Pendekatan Kebudayaan. Bandung: STSI Press.

Sedyawati, E. (1984). Tari: Tinjauan dari Berbagai Segi. Jakarta: Pustaka Jaya.

Soedarsono. (1990). Tayub, Penyajian dan Tata-Tarinya. Surakarta: Sebelas Maret University Press.

Strauss, L. (1988). Totemisme dalam Pandangan Strauss, dalam J. Van Baal, Sejarah dan Pertumbuhan Teori Antropologi. Jakarta: Gramedia, 1988.

Turner, Victor. (1986). The Ritual Process. New York: Cornel University Press

Wiyoso, J. (2011). Kolaborasi antara Jaran Kepang dengan Campursari: suatu Bentuk Perubahan Kesenian Tradisional. Harmonia Journal of Arts Research and Education, 11(1), 1-8. 